\title{
KARAKTER MORFOMETRIK, PERTUMBUHAN, DAN SINTASAN TIGA SPESIES IKAN SELUANG (FAMILI: CYPRINIDAE) ASAL PULAU BANGKA
}

\author{
Ahmad Fahrul Syarif* dan Eva Prasetiyono \\ *) Jurusan Akuakultur, Fakultas Pertanian, Perikanan dan Biologi, Universitas Bangka Belitung \\ Kampus Terpadu Balunjuk, Kecamatan Merawang, Kabupaten Bangka, Bangka Belitung 33172
}

(Naskah diterima: 13 Februari 2019; Revisi final: 9 Juni 2019; Disetujui publikasi: 10 Juni 2019)

\begin{abstract}
ABSTRAK
Penelitian ini bertujuan untuk mengevaluasi profil keragaman fenotipe ikan seluang (Rasbora) asal Pulau Bangka untuk pengembangan budidaya. Sampel ikan yang dikoleksi berasal dari lokasi sungai sekitar Desa Balunijuk, Kabupaten Bangka. Sebanyak tiga jenis ikan Seluang (Famili Cyprinidae) antara lain Rasbora einthovenii, Brevibora dorsiocellata, dan Trigionopoma gracile telah ditemukan. Pengukuran truss morfometrik dilakukan untuk melihat profil fenotipe ketiga spesies ikan seluang tersebut. Hasil penelitian menunjukkan bahwa penciri utama yang dapat membedakan ketiga spesies secara spesifik adalah perbandingan rasio truss morfometrik antara karakter panjang ekor (PE) dengan lebar badan III (LB-III). Persentase sintasan tertinggi pada Brevibora dorsicellata yang dipelihara pada pH 5-6 yaitu $93,30 \pm 5,80 \%$ sedangkan persentase sintasan terendah adalah Trigonopoma gracile dengan nilai 76,60 \pm 5,80\% dipelihara pada pH 5-6 dan 7 . Rasbora einthovenii yang dipelihara pada pH 5-6 menunjukkan nilai rata-rata pertambahan bobot mutlak yang lebih tinggi dibandingkan $\mathrm{pH}$ 7. Rata-rata pertambahan bobot mutlak dan pertambahan panjang mutlak pada Brevibora dorsiocellata dan Trigonopoma gracile memiliki kecenderungan lebih tinggi pada pemeliharaan di pH 5-6 dibandingkan $\mathrm{pH} 7$.
\end{abstract}

\section{KATA KUNCl: seluang; truss morfometrik; pertumbuhan; sintasan}

ABSTRACT: The morphometric characters, growth and survival rates of three species of rasbora fish (Family: Cyprinidae) from Bangka Island. By: Ahmad Fahrul Syarif and Eva Prasetiyono

\begin{abstract}
The research was aimed to evaluatethe phenotypes profile of rasbora fish from Bangka Belitung Islands for aquaculture development. Samples of rasbora fish were collected from the rivers near Balunijuk Village, Bangka Residence. Three species of rasbora (CyprinidaeFamily) which consisted of Rasbora einthovenii, Brevibora dorsiocellata, and Trigionopoma gracile.were collected. The truss morphometrics measurement was conducted to determine the phenotypic profiles of the three species. The results showed that the main identity characteristics to differentiate the three species were tail length (TL) and body width III (W-III). The highest survival rate was achieved by Brevibora dorsiocellata cultured in waters with pH 5-6 which was $93.30 \pm 5.80 \%$ The lowest survival rate was attained by Trigonopoma gracile which was $76.60 \pm 5.80 \%$ cultured in pH 5-6 and 7. The Rasbora einthovenii cultured in waters with pH 5-6 showed the highest absoluteweight gain compared to that of cultured in waters of pH 7. Brevibora dorsiocellata and Trigonopoma gracile tended to have better absolute weight and absolute length gain when cultured in waters with pH 5-6 compared to that of $\mathrm{pH} 7$.
\end{abstract}

KEYWORDS: rasbora; truss morphometric; growth; survival rate

\section{PENDAHULUAN}

Indonesia merupakan negara dengan keragaman hayati yang tinggi. Jika dibandingkan dengan Amerika Selatan, kekayaan hayati Indonesia menempati urutan kedua dengan spesies ikan air tawar dan laut mencapai

\footnotetext{
\# Korespondensi: Jurusan Akuakultur, Fakultas Pertanian, Perikanan dan Biologi, Universitas Bangka Belitung. Kampus Terpadu Balunjuk, Kecamatan Merawang, Kabupaten Bangka, Bangka Belitung 33172, Indonesia.

Tel.: + 62717422145

E-mail: ahmadfahrulsyarif@ yahoo.com
}

400 spesies dari 1.100 speies ikan yang ada di dunia (Kottelat et al., 1993). Luas perairan umum di Indonesia mencapai 55 juta hektar yang meliputi waduk, rawa, dan sungai dengan potensi pengembangan usaha budidaya sebesar 550 ribu hektar. Selain itu, daerah aliran sungai (DAS) juga memiliki kekayaan hayati dan biodiversitas ikan air tawar yang cukup tinggi misalnya DAS Sungai Batanghari, Jambi terdapat sekitar 14 ordo, 24 famili, dan 131 spesies ikan air tawar (Maskur, 2002). 
Secara khusus, penyebaran plasma nutfah ikan-ikan air tawar pada Kepulauan Bangka Belitung termasuk cukup tinggi. Karakteristik kepulauan yang khas menjadikan beberapa jenis ikan air tawar potensial untuk mulai dikembangkan sebagai salah satu spesies unggulan khas Kepulauan Bangka Belitung, misalnya Lekok (Chaca bankanensis), Sulur (Chana bankanensis), dan Seluang Bangka (Rasbora bankanensis). Khususnya ikan Seluang merupakan ikan yang potensial dikembangkan sebagai ikan hias lokal. Keindahan bentuk tubuh ikan ini menjadi daya tarik bagi para penghobi ikan hias. Ikan seluang dinilai potensial untuk dikembangkan sebagai ikan hias maupun konsumsi di daerah Sumatera. Ikan ini dikenal dengan nama Rasbora (Lumbantobing, 2014), pada beberapa daerah misalnya Aceh Tengah ikan sejenis yang dikembangkan adalah Depik (Rasbora tawarensis) (Hasri et al., 2011; Muchlisin, 2011). Di Pulau Jawa dikembangkan ikan dengan istilah ikan wader (Rasbora lateristriata, Rasbora argyrotaenia, Rasbora aprotaenia) (Budiharjo, 2002).

Informasi keragaman genetik suatu populasi merupakan informasi yang diperlukan dalam usaha perbaikan mutu benih, pengelolaan keragaman hayati di dalam suatu ekosistem, dan pengelolaan keanekaragaman genetik dalam gene pools spesies (Wijana, 1999). Keragaman genetik yang tinggi memiliki tingkat adaptasi yang lebih baik terhadap kondisi lingkungan hidupnya sehingga lebih lestari dalam jangka lama. Proses penyesuaian diri organisme dari alam yang kemudian dipelihara secara terkontrol dalam wadah budidaya akan memengaruhi respons fisiologi dan tingkah laku yang akan berdampak pada perubahan fenotipe biometriknya. Dalam hal ini, terdapat hubungan antara keragaman genetik dan kinerja produksinya (Gjederm, 2005). Kegiatan domestikasi pada ikan seluang asal Pulau Bangka belum pernah dilakukan. Penelitian ini bertujuan untuk mengevaluasi perbedaan karakter morfometrik beberapa spesies ikan seluang yang di temukan di Pulau Bangka dan mengukur respons adaptasinya berdasarkan kinerja pertumbuhan dan persentase sintasan di wadah budidaya pada tahap awal domestikasi.

\section{BAHAN DAN METODE}

\section{Koleksi Materi Uji}

Penelitian ini dilaksanakan pada bulan Agustus sampai dengan November 2017. Sampel ikan yang diperoleh berasal dari sungai di Desa Balunijuk, Kabupaten Bangka yang ditangkap menggunakan alat tangkap serok atau jala. Sejumlah masing-masing 30 ekor ikan hasil tangkapan kemudian dilakukan karakterisasi dan analisis sebaran morfometrik. Sebanyak 150 ekor ikan dikoleksi kemudian diadaptasikan untuk dilakukan uji coba pemeliharaan pada wadah budidaya (Tabel 1).

\section{Pengukuran Truss Morfometrik}

Sebelum melakukan pengukuran parameter morfometrik, ikan terlebih dahulu dipingsankan dengan menggunakan obat bius komersial Stabilizer Arowana ${ }^{\circledR}$ dengan dosis 1,5 mL larutan per satu liter air. Karakter morfometrik yang diukur meliputi delapan fenotipe truss (Gambar 1), pengukuran dilakukan dengan jangka sorong digital.

\section{Uji Coba Pemeliharaan pada Wadah Budidaya}

Uji coba pemeliharaan dilakukan di Hatchery dan Laboratorium Budidaya Perairan, Universitas Bangka Belitung. Kinerja produksi ikan seluang diukur melalui uji coba pemeliharaan dalam wadah budidaya dengan perbedaan pH yaitu 5-6 dan 7 dengan pengulangan sebanyak tiga kali pada masing-masing perlakuan. Hal ini mengacu pada kebiasaan dan habitat hidup ikan seluang di alam (Gosline, 1975). pH diatur dengan menambahkan larutan $\mathrm{HCl}$ (asam klorida) ke dalam air sediaan (stok) pada tandon, selanjutnya dilakukan pemantauan melalui alat $\mathrm{pH}$ meter digital sesuai perlakuan yang ditentukan. Wadah yang digunakan dalam uji coba pemeliharaan adalah berupa akuarium dengan dimensi $50 \mathrm{~cm} \times 30 \mathrm{~cm} \times 30 \mathrm{~cm}$ padat penebaran pada masing-masing akuarium adalah 10 ekor. Persiapan wadah pemeliharaan meliputi pencucian wadah dan pengisian air dengan volume 30 liter. Ikan seluang hasil koleksi yang diperoleh kemudian dilakukan pemuasaan dan aklimatisasi selama tujuh hari.

Pemeliharaan dilakukan selama 35 hari dengan frekuensi penggantian air 10\%15\% per hari yang dilakukan pada pagi hari. Selama pemeliharaan dilakukan pemberian pakan berupa pelet komersial (kandungan protein $39 \% 41 \%$ dengan frekuensi pemberian pakan sebanyak tiga kali sehari secara at satiation (sekenyangnya). Pengukuran kinerja produksi dilakukan setiap tujuh hari sekali meliputi sintasan ikan, pertambahan panjang, dan bobot. Pengukuran parameter produksi meliputi tingkat sintasan, pertambahan bobot mutlak, dan pertambahan panjang mutlak (Effendie, 1997).

\section{Analisis data}

Pengukuran morfometrik menggunakan rasio dilakukan untuk menghindari ketidakseragaman ukuran sampel yang diambil (Syarif et al., 2016). Delapan karakter fenotipe yang diukur selanjutnya dibuat tujuh rasio ukuran yang relevan yaitu: PK:PT, TK:PT, PB:PT, PE:PK, LBI:PK, LBII:PB, dan LBIII:PE. Tujuh rasio hasil pengukuran dianalisis ragam dengan selang 
Tabel 1. Bobot dan panjang awal sampel ikan seluang asal Pulau Bangka

Table 1. Intial weight and length of rasbora fish samples colleted on the study site

\begin{tabular}{lcc}
\hline $\begin{array}{c}\text { Nama spesies } \\
\text { Species name }\end{array}$ & $\begin{array}{c}\text { Bobot } \\
\text { Weight }(\mathbf{g})\end{array}$ & $\begin{array}{c}\text { Panjang } \\
\text { Length } \mathbf{( c m})\end{array}$ \\
\hline Rasbora einthovenii & $0.67 \pm 0.18$ & $3.77 \pm 0.19$ \\
Brevibora dorsiocellata & $0.46 \pm 0.07$ & $3.72 \pm 0.25$ \\
Trigonopoma gracile & $0.31 \pm 0.03$ & $3.20 \pm 0.15$ \\
\hline
\end{tabular}

* rata-rata \pm standar deviasi (averages \pm standard deviation)

kepercayaan 95\% menggunakan program SPSS 17.0 (MANOVA) guna menentukan karakter penciri, kemudian sebaran populasi berdasarkan rasio truss morfometrik tersebut dibuat dalam bentuk diskriminan kanonikal. Parameter kinerja produksi (sintasan, pertambahan bobot mutlak, dan pertambahan panjang mutlak) diolah menggunakan Microsoft Excel 2013 dan dianalisis secara deskriptif.

\section{HASIL DAN BAHASAN}

\section{Truss Morfometrik Ikan Seluang Asal Pulau Bangka}

Tiga jenis ikan seluang (Famili: Cyprinidae) pada lokasi penelitian (Gambar 2), ketiga spesies ikan seluang ini tergolong dalam kelompok ikan-ikan rasbora dengan nama spesifikasi dan sebaran spesies tercantum pada Tabel 2.
Ikan seluang (rasbora) ditemukan di sungai bagian hulu dan hilir, sungai besar, danau besar dan kecil, kolam, selokan di samping jalan, dan di sawah. Spesies rasbora dengan ukuran yang besar dapat ditemukan di sungai yang besar, sementara yang berukuran kecil umumnya ditemukan di sungai kecil, selokan, sawah, dan sebagainya. Pada beberapa daerah di Indonesia, ikan ini ditemukan di lokasi sebagai berikut: Sungai Kapuas, Kalimantan Barat (Roberts, 1989); sungai di daerah Malay Peninsula; Sungai Moesi, Sumatera (Brittan, 1954), Sungai Landak, Pontianak (Siebert, 1997); dan Sungai Sarawak, Malaysia (Parenti \& Lim, 2005) serta Kalimantan Tengah (Prakoso, 2014).

Hasil ilustrasi fenotipe berdasarkan sebaran karakter morfometrik (rasio truss morfometrik) dari tiga spesies ikan seluang menunjukkan bahwa penciri utama dari ketiga spesies ini adalah lebar badan III

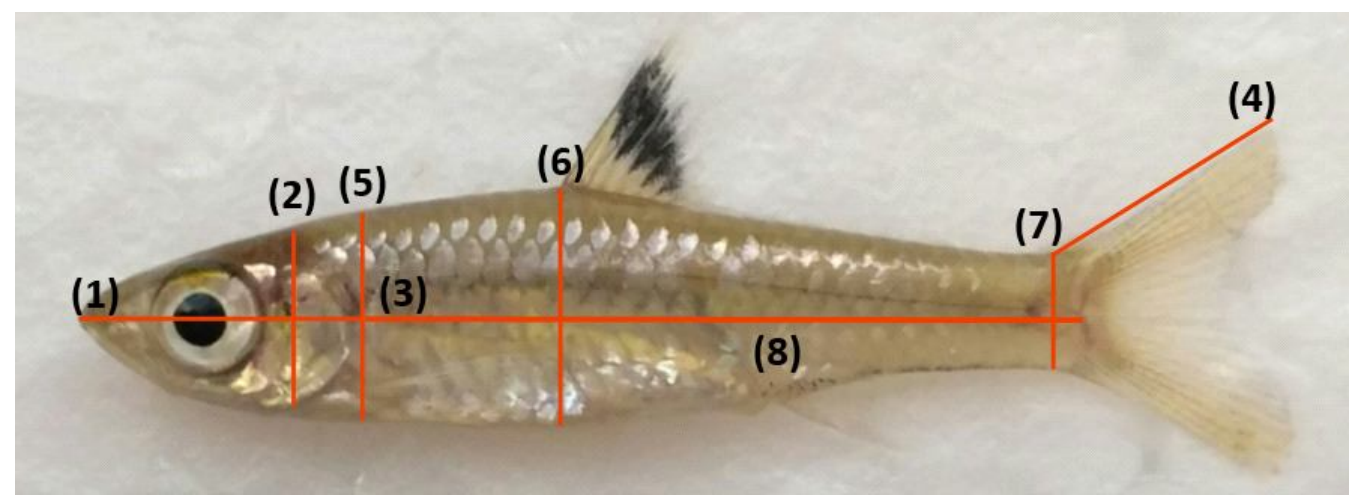

Keterangan:

1) Panjang bagian kepala (PK), yaitu jarak dari ujung anterior mulut sampai tepian tutup insang

2) Tinggi kepala (TK), yaitu jarak kepala atas sampai bawah tutup insang

3) Panjang bagian badan (PB), yaitu jarak dari pinggir kaudal tutup insang sampai anus

4) Panjang bagian ekor (PE), yaitu jarak dari anus sampai ujung posterior

5) Lebar badan I (LBI), yaitu jarak antara sisi kiri dan kanan badan tepat di tepian tutup insang (posisi specimen dorsoventral)

6) Lebar badan II (LBII), yaitu jarak antara sisi kiri dan kanan badan di tengah-tengah LBI dan LBIII (posisi specimen dorsoventral)

7) Lebar badan III (LBIII), yaitu jarak antara sisi kiri dan kanan badan tepat di depan anus (posisi specimen dorsoventral)

8) Panjang total (PT), yaitu jarak dari ujung anterior sampai ujung posterior

Gambar 1. Karakter morfometrik ikan seluang (modifikasi dari Wijana, 1999).

Figure 1. The morphometrics characters of rasbora fish (based on Wijana, 1999). 

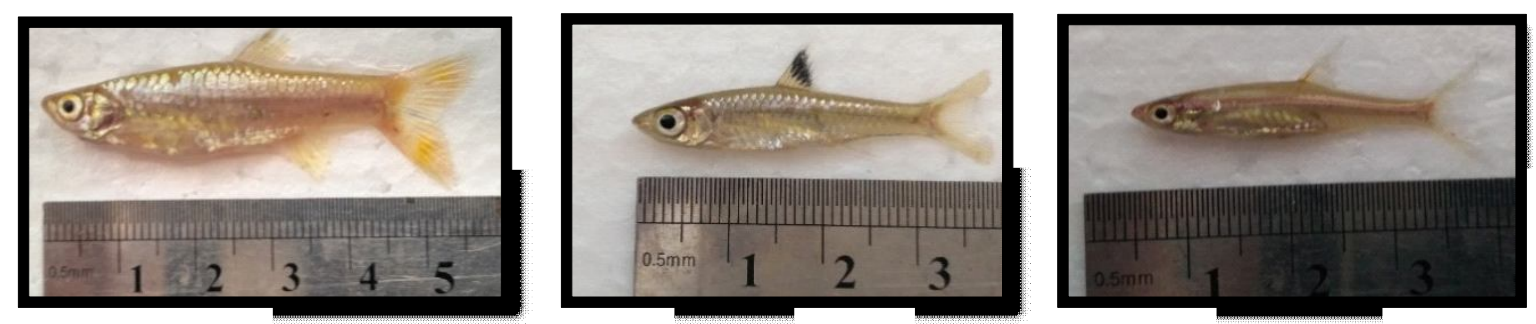

Gambar 2. Tiga jenis ikan seluang: a) Rasbora einthovenii; b) Brevibora dorsiocellata; c) Trigonopoma gracile.

Figure 2. Three types of Rasbora: a) Rasbora einthovenii; b) Brevibora dorsiocellata; c) Trigonopoma gracile.

Tabel 2. Spesifikasi dan karakteristik ikan seluang asal Pulau Bangka

Table 2. General descriptions of rasbora fish from Bangka Island

\begin{tabular}{cccc}
\hline $\begin{array}{c}\text { Nama spesies } \\
\text { Species name }\end{array}$ & $\begin{array}{c}\text { Distribusi dan Sebaran* } \\
\text { Distribution* }\end{array}$ & $\begin{array}{c}\text { Nama populer } \\
\text { Popular name }\end{array}$ & $\begin{array}{c}\text { Fungsi potensi } \\
\text { Potential function }\end{array}$ \\
\hline Rasbora einthovenii & Asia : Malay peninsula dan Indonesia & Briliant Rasbora & $\begin{array}{c}\text { Ikan hias dan konsumsi } \\
\text { Ornamental fish and consumption } \\
\text { Ikan hias }\end{array}$ \\
Brevibora dorsiocellata & Asia : Malay peninsula dan Indonesia & Eyespot Rasbora & $\begin{array}{c}\text { Ornamental fish } \\
\text { Ikan hias } \\
\text { Trigonopoma gracile }\end{array}$ \\
Asia : Malaysia dan Indonesia & Redline Rasbora & Ornamental fish \\
\hline
\end{tabular}

* Sumber (Source): www.fishbase.org (2019)

(LB-III) dan panjang ekor (PE) berdasarkan sidik ragam Multivariate Analysis of Variance (MANOVA) dengan selang kepercayaan 95\%(Tabel 3). Melalui penciri dari karakter morfometrik ini tiga spesies ikan seluang dapat dibedakan secara jelas dan spesifik. Hal ini menunjukkan bahwa ikan membentuk sub-divisi dari setiap spesies akibat dari adanya isolasi. Jika populasi berada pada lingkungan yang sama atau terjadi kesinambungan yang terus-menerus maka migrasi dan aliran gen akan terus berlangsung. Di antara individu tersebut akan menampakkan banyak kesamaan baik fenotipe maupun genotipe. Sebaliknya, bila populasi berada pada suatu lingkungan yang sangat kontras dan atau terjadi perubahan dengan sedikit migrasi kemungkinan besar akan terjadi perubahan struktur populasi. Faktor-faktor ini, akan memengaruhi variasi genetik dan ukuran populasi aslinya, serta memengaruhi heterozigositas dalam suatu spesies (Carvalho, 1993).

Pola sebaran yang tergambar oleh fungsi diskriminan kanonikal menunjukkan perbedaan yang spesifik pada tiga populasi ikan seluang asal Pulau Bangka. Pola sebaran grup centroid terlihat setiap spesies menunjukkan perbedaan yang khusus, namun terlihat pola sebaran yang masih bersinggungan antara spesies Trigonopoma gracile dan Brevibora dosrsiocellata sedangkan spesies Rasbora einthovenii terpisah jauh (Gambar 3). Variasi interaksi antara genotipe dan lingkungan muncul karena adanya kontribusi beberapa alel yang bertanggung jawab terhadap kenampakan fenotipe yang terekspresi secara berkala dalam lingkungan yang berbeda (Westra, 1994). M isalnya pada ikan botia (Chromombotia macrachanthus) pada penelitian yang dilakukan Sudarto \& Rizal (2007), terjadi perbedaan karakter morfometrik pada kedua lokasi dan kondisi lingkungan yang berbeda. Tiga spesies ikan seluang asal Pulau Bangka (Gambar 2) memiliki perbedaan secara fenotipe ditunjukan dengan adanya perbedaan pada karakter panjang ekor (PE) dibandingkan lebar badan 3 (LBIII). Menurut Kristanto \& Kusrini (2007), karakter morfometrik yang berbeda dapat digunakan sebagai penciri kelompok populasi untuk membedakan dengan populasi lainnya.

\section{Sintasan dan Pertumbuhan Ikan Seluang asal Pulau Bangka}

Uji coba pemeliharaan ikan seluang selama 35 hari (Tabel 4) dengan perbedaan $\mathrm{pH}$ menunjukkan bahwa rata-rata persentase sintasan selama pemeliharaan pada wadah budidaya di atas $70 \%$ dengan persentase 
Tabel 3. Nilai rasio morfometrik tiga spesies ikan seluang asal Pulau Bangka

Table 3. The morphometrics ratios value of three rasbora fish species from Bangka Island

\begin{tabular}{ccccc}
\hline $\begin{array}{c}\text { Rasio karakter morfometrik } \\
\text { Morphometrics character ratios }\end{array}$ & Rasbora einthovenii & Brevibora dorsiocellata & Trigonopoma gracille & $\begin{array}{c}\text { Signifikasi } \\
\text { Signification }\end{array}$ \\
\hline PK:PT & 0,182 & 0,193 & 0,197 & 0,565 \\
TK:PT & 0,126 & 0,132 & 0,121 & 0,579 \\
PB:PT & 0,594 & 0,596 & 0,589 & 0,400 \\
PE:PK & 0,223 & 0,211 & 0,214 & 0,082 \\
LBI:PK & 0,904 & 0,880 & 0,727 & 0,212 \\
LBII:PB & 0,337 & 0,322 & 0,275 & 0,201 \\
LBIII:PE & 0,456 & 0,403 & 0,351 & $\mathbf{0 , 0 0 3}$ \\
\hline
\end{tabular}

Keterangan (Note): * Karakter yang berbeda $(P<0,05)$ (Differ ent character $(P<0.05))$

PK (panjang kepala); PB (panjang badan); PT (panjang total); PE (panjang ekor); PH (panjang hidung);

LBI (lebar badan 1); LBII (lebar badan 2); LBIII (lebar badan 3)

sintasan tertinggi pada spesies Brevibora dorsicellata yang dipelihara pada pH 5-6 yaitu 93,30 $\pm 5,80 \%$ Persentase sintasan terendah secara umum terlihat pada spesies Trigonopoma gracile dengan nilai sintasan yaitu 76,60 \pm 5,80\%yang dipelihara pada pH 5-6 dan 7. Spesies Rasbora einthovenii yang dipelihara pada $\mathrm{pH}$ 5-6 menunjukkan nilai rata-rata pertambahan bobot mutlak yang lebih tinggi dibandingkan $\mathrm{pH} 7$, namun pada rata-rata pertambahan panjang mutlak menunjukkan nilai yang sebaliknya. Rata-rata pertambahan bobot mutlak dan petumbuhan panjang mutlak pada spesies Brevibora dorsiocellata dan Trigonopoma gracile memiliki kecenderungan lebih tinggi pada pemeliharaan di $\mathrm{pH}$ 5-6 dibandingkan $\mathrm{pH}$ 7 (Tabel 4).
Aklimatisasi merupakan proses penyesuaian organisme terhadap perubahan kondisi lingkungan di alam dengan pemeliharaan secara terkontrol. Perubahan lingkungan dapat memengaruhi tingkah laku organisme secara fisiologis yang akan tergambar pada perubahan fenotipe dan kinerja produksinya (Gjederm, 2005). Sintasan dalam pemeliharaan tiga spesies ikan seluang menunjukkan tingkat sintasan yang baik yaitu di atas 70\%(Tabel 4). Setiap ikan memilliki perbedaan toleransi terhadap kondisi $\mathrm{pH}$ perairan, namun umumnya kelompok ikan seluang cenderung bertahan pada $\mathrm{pH}$ yang relatif asam. Said et al. (2011) dan Ginanjar et al. (2014) dalam penelitiannya terhadap ikan Rasbora agryotaenia menyatakan bahwa kelompok ikan ini cenderung hidup pada $\mathrm{pH}$ asam yaitu 5,5. Dalam

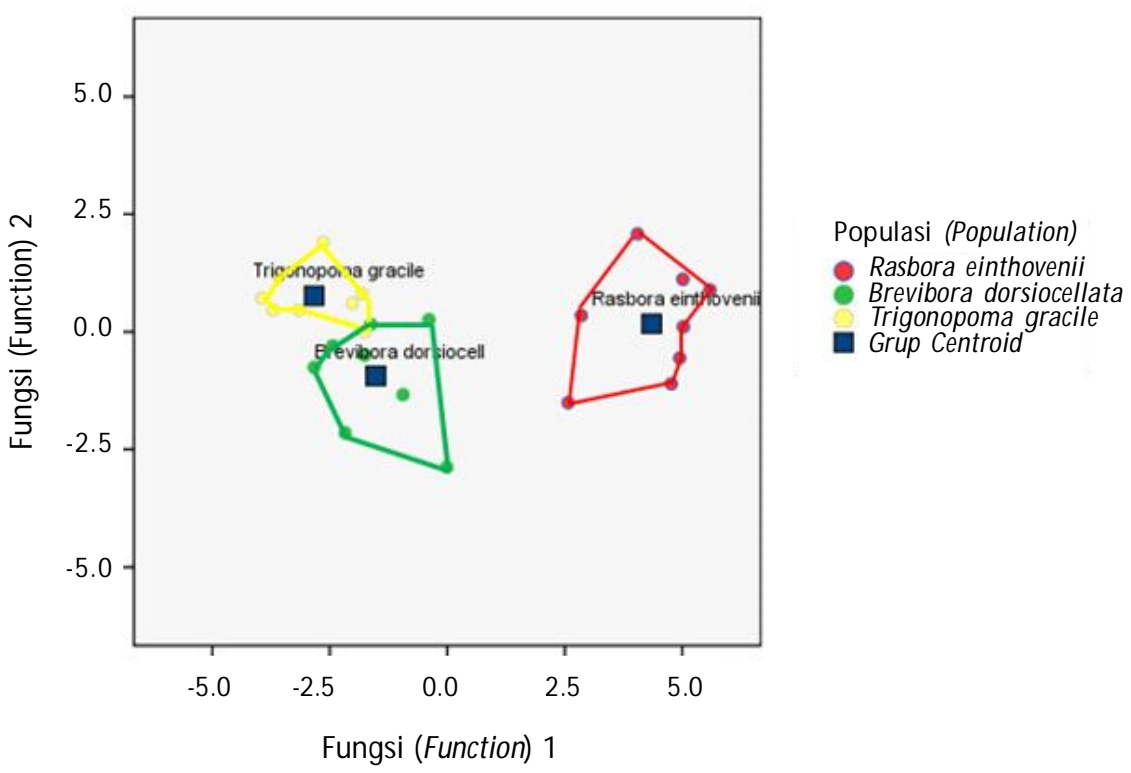

Gambar 3. Fungsi diskriminan kanonikal sebaran rasio truss morfometrik tiga spesies ikan seluang asal pulau Bangka.

Figure 3. Canonical discriminant function distributions of the morphometric truss ratios of three rasbora fish species from Bangka Island. 
Tabel 4. Rata-rata sintasan, pertambahan bobot mutlak, dan pertambahan panjang mutlak tiga spesies ikan seluang selama 35 hari pemeliharaan.

Table 4. The averages of survival rate, growth and length of three rasbora fish species during 35 days culture

\begin{tabular}{lcccc}
\hline \multicolumn{1}{c}{$\begin{array}{c}\text { Parameter } \\
\text { Parameters }\end{array}$} & \multirow{2}{*}{$\begin{array}{c}\text { Perlakuan } \\
\text { Treatments }(\mathbf{p H})\end{array}$} & \multicolumn{3}{c}{ Nama spesies (Species name) } \\
\cline { 3 - 6 } & & Rasbora einthovenii & Brevibora dorsiocellata & Trigonopoma gracille \\
\hline Sintasan & 7 & $80.00 \pm 0.00$ & $85.70 \pm 5.80$ & $76.60 \pm 5.80$ \\
Survival rate $(\%)$ & $5-6$ & $76.60 \pm 5.80$ & $93.30 \pm 5.80$ & $76.60 \pm 5.80$ \\
\hline Pertambahan bobot mutlak & 7 & $0.15 \pm 0.04$ & $0.05 \pm 0.04$ & $0.01 \pm 0.01$ \\
Absolute weight gain $(\mathrm{g})$ & $5-6$ & $0.18 \pm 0.02$ & $0.06 \pm 0.06$ & $0.02 \pm 0.03$ \\
\hline Pertambahan panjang mutlak & 7 & $0.52 \pm 0.40$ & $0.07 \pm 0.05$ & $0.20 \pm 0.00$ \\
Absolute length increment $(\mathrm{cm})$ & $5-6$ & $0.13 \pm 0.05$ & $0.34 \pm 0.12$ & $0.29 \pm 0.27$ \\
\hline
\end{tabular}

hal ini, kondisi perairan di Pulau Bangka menunjukkan derajat keasaman airyang relatif rendah (Muslih, 2014). Kondisi ini menyebabkan pola adaptasi yang unik terhadap beberapa spesies lokal terutama kelompok ikan seluang yang berasal dari Pulau Bangka. Menurut Ferguson et al. (1995), proses adaptasi lokal yang sudah berlangsung lama akan memengaruhi variasi genetik spesifik (wild) sebagai sumber genetik yang stabil dan memiliki peranan penting untuk ketahanan dan kelestarian suatu populasi (potential fitness).

Perubahan lingkungan dapat memengaruhi tingkah laku organisme secara fisiologis yang akan tergambar dari perubahan fenotipe dan kinerja produksinya (Tabel 3). Dalam penelitian ini respons pertumbuhan (panjang dan bobot) pada tiga spesies ikan seluang menunjukkan bahwa kecenderungan $\mathrm{pH}$ yang lebih rendah tidak berpengaruh pada kemampuan tumbuhnya (Tabel 4). Padahal idealnya beberapa spesies ikan budidaya lebih nyaman pada media pemeliharaan berkisar antara 6,57,5 (Said et al., 2011). Keragaan pertumbuhan merupakan indikator yang penting terkait dengan keberhasilan domestikasi dan budidaya. Pada organisme yang sudah berhasil didomestikasi pada umumnya menunjukkan pertumbuhan yang lebih seragam dibandingkan dengan populasi di alam. Respons biometrik terkait keragaan pertumbuhan merupakan indikator keberhasilan respons adaptasi biota terhadap lingkungan pada proses domestikasi maupun budidaya (Syarif et al., 2016).

\section{KESIMPULAN}

Profil fenotipe tiga spesies ikan seluang menunjukan perbedaan karakter rasio truss morfometrik yaitu panjang ekor (PE) dibandingkan dengan lebar badan 3 (LBIII). Rata-rata persentase sintasan tiga spesies ikan seluang asal Pulau Bangka selama pemeliharaan pada wadah budidaya di atas $70 \%$ Spesies Rasbora einthovenii yang dipelihara pada
pH 5-6 menunjukkan pertambahan bobot mutlak terbaik, namun pertambahan panjang mutlak terbaik terdapat pada pemeliharaan di pH 7. Spesies Brevibora dorsiocellata dan Trigonopoma gracile memiliki kecenderungan pertambahan bobot mutlak dan pertambahan panjang mutlak yang lebih tinggi pada pemeliharaan di pH 5-6 dibandingkan $\mathrm{pH}$ 7. Secara umum pada tahap awal domestikasi kinerja produksi menunjukkan respons yang cukup positif.

\section{UCAPAN TERIMA KASIH}

Ucapan terima kasih ditujukan kepada Universitas Bangka Belitung terkait pendanaan penelitian dosen tingkat jurusan tahun 2017. Saudara Dobi Irawan, S.Pi. dan rekan yang telah membantu kelancaran penelitian ini sehingga dapat berjalan dengan baik dan semoga hasil yang diperoleh bermanfaat bagi dunia akuakultur secara umum.

\section{DAFTAR ACUAN}

Brittan, M.R. (1954). A revision of the Indo-Malayan freshwater fish genus Rasbora. Manila: Monographs of the Institute of Science and Technology, p. 1-224.

Budiharjo, A. (2002). Seleksi dan potensi budidaya jenis-jenis ikan wader dari genus rasbora. Biodiversitas, 3(2), 225-230.

Carvalho, G.R. (1993). Evolutionary aspect of fish distribution: genetic variability and adaptation. Journal of Fish Biology, 43(Suppl. A), 53-73.

Effendie, M.I. (1997). Biologi perikanan. Yogyakarta: Yayasan Pustaka Nusatama, $112 \mathrm{hlm}$.

Ferguson, A., Taggart, J.B., Prodohl, P.A., McMeel, O., Thompson, C., Stone, P., McGinnity, P., \& Hynes, R.A. (1995). The aplication of molecular markers to the study and conservation of fish population, with special reference to salmo. Journal of Fish Biology, 47(Suppl. A), 103-126. 
Ginanjar, R., Zamroni, M., \& Nurhidayat. (2014). Optimalisasi rasio kelamin yang berbeda pada pemijahan ikan hias rasbora (Rasbora agryotaenia). Prosiding Forum Inovasi Teknolgi Akuakultur, hlm. 947-955.

Gjederm, T. (2005). Selection and breeding programs in aquaculture. Dordrecht: Springer Science \& Business Media, 364 pp.

Gosline, W.A. (1975). The cyprinid dermosphenotic and the subfamily Rasborinae. Occasional papers of the Museum of Zoology, Universitas Michigan, 73, 116.

Hasri, I., Kamal, M.M., \& Zairion. (2011). Pertumbuhan dan laju eksploitasi ikan endemik Rasbora tawarensis (Weber $\&$ de Beaufort, 1916) di Danau Laut Tawar, Aceh Tengah. Jurnal Iktiologi Indonesia, 11(1), 21-28.

Kottelat, M., Whitten, A.J., Kartikasari, S.N., \& Wirjoatmodjo, S. (1993). Freshwater Fishes of Western Indonesia and Sulawesi. Periplus Editions Limited: Jakarta, 221 pp.

Kristanto, A. \& Kusrini, E. (2007). Peranan faktor lingkungan dalam pemuliaan ikan. Media Akuakultur, 2(1), 183-188.

Lumbantobing, D.N. (2014). Four new species of Rasbora of theSumatrana group (Teleostei: Cyprinidae) from Northern Sumatra Indonesia. Zootaxa, 3764 (1), 1-25.

Maskur. (2002). Program pelestarian plasma nutfah ikan-ikan perairan umum. Jurnal Akuakultur Indonesia, 1(3), 139-144.

Muslih, K. (2014). Pengaruh penambangan timah terhadap keanekaragaman ikan sungai dan kearifan lokal masyarakat di Kabupaten Bangka. Tesis. Sekolah Pascasarjana, Institut Pertanian Bogor.

Muchlisin, Z.A. (2011). Spawning sites of depik, Rasbora tawarensis (Teleostei, Cyprinidae) in Lake Laut Tawar, Indonesia. Proceedings of The Annual International Conference Syiah Kuala University, $1(1), 95-99$.
Parenti, L.R. \& Lim, K.K.P. (2005). Fishes of the Rajang Basin, Sarawak, Malaysia. The Raffles Bulletin of Zoology, 13, 175-208.

Prakoso, D.R. (2014). Deskripsi dan distribusi ikan genus Rasbora pada kelompok spesies Rasbora sumatrana dan kelompok spesies Rasbora trifasciata di Tenggara Kalimantan, Indonesia. Skripsi. Fakultas Matematika dan IImu Pengetahuan Alam: Universitas Indonesia.

Roberts, T.R. (1989). The Freshwater Fishes of Western Borneo (Kalimantan Barat, Indonesia). California Academy of Sciences: San Fransisco, 210 pp.

Said, D.S., Triyanto, \& Mayasari, N. (2011). Respons biologis ikan hias endemik dan asli Indonesia terhadap perubahan keasaman dan suhu air. Prosiding Seminar Nasional Ikan ke VI, 1(1), 169177.

Sudarto, \& Rizal, M. (2007). Variasi morfometri ikan botia (Botia macracanthus Bleeker) dari perairan Sumatera dan Kalimantan. Jurnal Perikanan (Journal of Fisheries Science), 9(2), 214-219.

Syarif, A.F., Soelistyowati, D.T., \& Affandi, R. (2016). Keragaman fenotipe tiga populasi belut Monopterus albus (Zuiew, 1793) asal Jawa Barat dan respons biometrik pada media air bersalinitas. Jurnal Iktiologi Indonesia, 16(2), 133-143.

Siebert, D.J. (1997). The identities of Rasbora paucisqualis (Ahl in Schreitmller, 1935), and Rasbora bankanensis (Bleeker, 1853), with the designation of a lectotype for R. paucisqualis (Teleostei: Cyprinidae). The Raffles Bulletin of Zoology, 45, 29-37.

Westra, I.G.K.P. (1994). Dasar-dasar genetika ikan dan pengembangbiakan: genetika kualitatif, genetika populasi, seleksi. Surabaya: Airlangga University Press, $75 \mathrm{hlm}$.

Wijana, I.M.S. (1999). Keragaman enzim dan morfologi belut, Monopterus albus Zuiew (Synabranchidea: Synabarnchidae). Tesis. Institut Pertanian Bogor, $54 \mathrm{hlm}$. 